\title{
The Structure of Executive Compensation, the Choice of Accounting Policies and the Value of Corporation
}

\author{
Wang Xing ${ }^{1, a}$, Wu Fengping ${ }^{2, b}$, Wang Quen ${ }^{3, c}$ \\ ${ }^{1 .}$ Business Administration Faculty of Hohai University, Changzhou, Jiangsu Province, China \\ Post code: 213022; \\ 2. Business Administration Faculty of Hohai University, Changzhou, Jiangsu Province, China \\ Post code: 213022; \\ 3. Business Administration Faculty of Hohai University, Changzhou, Jiangsu Province, China \\ Post code: 213022 \\ awangxing@hhuc.edu.cn, bwfp@hhu.edu.cn, 'wangquen110@sina.com
}

Keywords: Executive compensation structure; Financial assets; Corporate value; Intermediary effect

\begin{abstract}
In this paper, the new standards division of listed corporation financial assets of the accounting policy choice as an opportunity makes an empirical study of the relationship between executive compensation structure and firm value. This paper selects the number of 2819 listed corporation annual report as full samples which were during the time of period from 2007 to 2011 , and this was the basic situation of the structure of executive compensation, financial assets and the value of the company to the sample firms being a descriptive statistical analysis. Through multiple regression analysis, the significant correlation between executive compensation structure, the choice of accounting policy and the company value, and on the basis of intermediary effect on the choice of accounting policy are analyzed, leading to the accounting policy choice in compensation and corporate executives value share the intermediary effect with each other.
\end{abstract}

\section{Introduction}

Due to the separation of the management power and ownership, top managements are main makers and executives of the management and control system in today's companies, leading to the distinction of the role and profit between managers and owners. In order to pursue the same target between top managers and shareowners, they need to have the management remuneration contract. For executives, the majority incentive elements of the increasingly fortune is the equity compensation, which exists in the structure of individual salary and company's value. The payment can not only stimulate the personal benefit of top managements, but also make the aim between individual and stockowners be similar, reducing the cost. Therefore, combined with the personal interest and the enterprise top management's profit ability and development ability, under the contrast, executives are able to control the corporations, establish the related system, pick up the approaches of controlling the companies and soar its value eventually. One of the main ways in the controlling process is accounting choice policy, which may affect the decision of corporation if executives do their decisions as the requirements of the accounting standards and rules, and changes will turn up in the reports of the companies finally.

Management layers may have influence on the current and future firm value if they divide the decision into trading financial assets and financial assets available for sale, the division provides the time and space of the profit for managements. The paper aims to have research on structure of the executive's compensation and the impact on companies' values made by policies-choice ,and to take the further step to versify whether via the choice of accounting policy, compensation structure may affect the value, which is the intermediary effect.

\section{Literature review and research hypothesis}

In 1980s, Watts and Zimmerman ${ }^{[1]}(1986)$ established three hypothesis which are political, payment and debt contract hypothesis on the basis of contract theory and they carried on many empirical researches at the center of it. $\operatorname{Abdel}^{[2]}(1985)$,Healy ${ }^{[3]}(1985)$, Beatty and Weber ${ }^{[4]}(2003)$ 's empirical study had verified the relationship between policy-changing and political contract theory and payment and debt hypothesis. It is obvious that foreign scholars prefer to use the structure of 
the executives, background and gap among payment to exam the outcome of the company performance. E.g. Jensen and Meekling ${ }^{[5]}(1976)$ put forward the "The convergence of interest hypothesis" and believed that the more shares managers held, more similar profit between external shareowners and them, leading to higher value. Stulz ${ }^{[6]}(1988)$ showed "Defensive trenches hypothesis" and confirmed that to a proportion of shareholding, executives may defend the external monitoring system and have negative effect on performance. In general, western scholars think that compensation structure has either positive or negative effect on corporation's value.

In recent years, with the deeper and wider study on accounting policy choice, the domestic scholars have focused on the value changing of the company. E.g. Zhang Junrui, Zhao Jinwen and Zhang $\operatorname{Jian}^{[7]}(2003)$ proposed that top managerial salary was influenced by per share earnings and the earnings were affected by political choice. Thus, management layer used it to improve the accountancy profit and to maximize the individual benefit. Wang $\operatorname{Kun}^{[8]}(2011)$ checked the combination of the accounting political choice among listing corporations and believed that the choice would affect the value significantly. Ye Jianfang and Zhou $\operatorname{Lan}^{[9]}(2009)$ verified that the subjective motivation may change with the variety of the financial assets under the profit fluctuation. Zhang $\mathrm{Li}^{[10]}(2010)$ thought that the financial assets' division of political choice was related to the earnings management. He Hui ${ }^{[11]}(2011)$ confirmed that the variety of financial assets produced investment income, affecting executives' compensation eventually and the incline of division may have impact on its level.

From the existing work, although scholars from different countries carried out a large number of the theoretical and empirical study at the managerial contrast theory on the basis of three hypothesis, and they verified the relationship between three groups, such as payment structure and companies' value, the former scholars did not show the relative empirical study about how the two elements mentioned before influenced the value of corporation, their approaches and the importance of the function. Hence, the innovation of the paper is to look for the mutual relationship between three individuals to hope for the new thinking on the research and to find the ingredients affecting enterprise's value, the ways and functions. Then, the paper can give out a new perspective on incentive, control structure and research approaches.

Salary and stock incentive will have a positive impact on business performance and this leads to the smaller difference between executives and shareowners at corporate governance. However, the different incentive way may focus on the range of respects of governance. E.g. Mehran Hamid ${ }^{[12]}$ (1995)checked the stimulation theories among 153 companies which were selected randomly from 1979 to 1980, and he made the results that elements composed of payment can make managers work hard and higher compensation can improve the corporate value efficiently. According to the managerial and agent theories, as owners, shareowners will modify properly at the compensation structure in order to stimulate the top managers to pick up and add the entire fortune. Thus, the paper proposes the hypothesis below:

H1: Equity compensation accounts for a larger proportion of executive compensation structure will motivate executives to make the right decision of enhancing value.

When classifying the financial assets, the treatment of trading financial assets will increase the company's profits fluctuation, and also makes executives in performance management produce corresponding changes. This paper shows the following hypothesis:

$\mathrm{H} 2$ : Equity compensation accounts for a larger proportion of executive compensation structure will lead executives to divide financial assets into trading financial ones.

According to the management compensation hypothesis, to improve the managements' benefit, they tend to get future earnings in the current. Combined with the trading financial assets and financial assets available for sale in the subsequent measurement characteristics, the paper assumes:

H3: Executives tend to divide the financial assets into trading financial assets, causing the relatively higher value.

On the basis of that as the decision-makers who are based on the stimulation system of the corporation owners, they use the choice of accounting policy affecting profits during the managing process to maximize the value and improve own benefits, outlined the assumption: 
H4: There is an intermediary effect of accounting choice policy from executive equity compensation structure affecting executives of financial assets classification, and then affecting the overall value of the enterprise.

\section{Research design}

Choice of samples: This paper selects corporations which are listed in the stock of Shanghai and Shenzhen between 2007 and 2011, and all the data are from CCER, ruling out the incorrect companies, which have features of (i) financial companies with their characteristics (ii) lacking statistics (iii) having less than two financial assets. Finally, the paper has 2819 samples.

Design of variables and research model: Specific variable design can be seen from Table 1:

Table 1: Settings Summary of Research on Variable

\begin{tabular}{|c|c|c|}
\hline Variable name & Variable symbol & Formulas \\
\hline $\begin{array}{l}\text { Enterprise value } \\
\text { (dependent variable) }\end{array}$ & Y & $\begin{array}{l}\text { Tobin } \mathrm{Q}=(\text { year-end-circulation market value }+ \text { year-end } \\
\text { non-tradable share of net assets amount }+ \text { total long-term } \\
\text { liabilities }+ \text { total short-term liabilities }) / \text { Year-end assets }\end{array}$ \\
\hline $\begin{array}{l}\text { Financial assets ratio } \\
\text { (intermediary variable } \mathrm{M} \text { ) }\end{array}$ & FAR & $\begin{array}{l}=\text { Trading financial assets } / \text { (trading financial assets }+ \text { financial } \\
\text { assets available for sale) } * 100 \%\end{array}$ \\
\hline $\begin{array}{l}\text { Structure of executive } \\
\text { compensation } \\
\text { (independent variable) }\end{array}$ & ESS & $\begin{array}{l}\text { Equity incentive strength }=\text { number of executive shares of } \\
\text { stock *year-end price } /(\text { salary }+ \text { number of executives holding } \\
\text { shares stock * year-end price }) * 100 \%\end{array}$ \\
\hline \multirow{5}{*}{ Control variables } & SIZE & $\begin{array}{l}=\text { The natural logarithm of total assets of the enterprise } \\
\text { accounting }\end{array}$ \\
\hline & PROFIT & $\begin{array}{l}\text { Rate of return on net assets }=\text { net income / average balance of } \\
\text { the rights and interests of the owners } * 100 \%\end{array}$ \\
\hline & PRP & Property ratio $=$ Total Liabilities $/$ total stockholders equity \\
\hline & $\mathrm{IND}_{1-11}$ & Industry dummy variables \\
\hline & $\mathrm{YEAR}_{1-4}$ & The annual dummy variables \\
\hline
\end{tabular}

According to the assumptions above, the paper uses the following models (Eq.1,Eq.2 and Eq.3):

$$
\begin{aligned}
& \mathrm{Y}=\mathrm{a} 1+\mathrm{b} 1 \mathrm{ESS}+\mathrm{c} 1 \mathrm{SIZE}+\mathrm{d} 1 \mathrm{PROFIT}+\mathrm{e} 1 \mathrm{PRP}+\sum \mathrm{IND}_{1-11}+\sum \mathrm{YEAR}_{1-4}+\varepsilon \\
& \mathrm{FAR}=\mathrm{a} 2+\mathrm{b} 2 \mathrm{ESS}+\mathrm{c} 2 \mathrm{SIZE}+\mathrm{d} 2 \text { PROFIT }+\mathrm{e} 2 \mathrm{PRP}+\sum \mathrm{IND}_{1-11}+\sum \mathrm{YEAR}_{1-4}+\varepsilon \\
& \mathrm{Y}=\mathrm{a} 3+\mathrm{b} 3 \mathrm{FAR}+\mathrm{c} 3 \mathrm{SIZE}+\mathrm{d} 3 \text { PROFIT }+\mathrm{e} 3 \mathrm{PRP}+\sum \mathrm{IND}_{1-11}+\sum \mathrm{YEAR}_{1-4}+\varepsilon
\end{aligned}
$$

From the intermediary effect, the paper establishes the model 4(Eq.4):

$$
\mathrm{Y}=\mathrm{a} 4+\mathrm{b} 4 \mathrm{ESS}+\mathrm{b} 5 \mathrm{FAR}+\mathrm{c} 4 \mathrm{SIZE}+\mathrm{d} 4 \mathrm{PROFIT}+\mathrm{e} 4 \mathrm{PRP}+\sum \mathrm{IND} 1-11+\sum \text { YEAR11-14+ } \varepsilon
$$

\section{Empirical results and analysis}

Descriptive statistics of the main variables: According to the variables setting, the research uses the SPSS19 to produce the correlation analysis of main variables from Table 2.

Table 2: Pearson Correction

\begin{tabular}{ccccccc}
\hline & $\mathrm{Y}$ & FAR & ESS & SIZE & PROFIT & PRP \\
\hline $\mathrm{Y}$ & 1 & $.144^{* *}$ & $.096^{* *}$ & $-.463^{* *}$ & $.052^{* *}$ & $-.250^{* *}$ \\
FAR & $.144^{* *}$ & 1 & $.038^{*}$ & $-.163^{* *}$ & .027 & $-.040^{*}$ \\
$\mathrm{ESS}$ & $.096^{* *}$ & $.038^{*}$ & 1 & .033 & .003 & $-.075^{* *}$ \\
SIZE & $-.463^{* *}$ & $-.163^{* *}$ & .033 & 1 & -.006 & $.256^{* *}$ \\
PROFIT & $.052^{* *}$ & .027 & .003 & -.006 & 1 & -.009 \\
PRP & $-.250^{* *}$ & $-.040^{*}$ & $-.075^{* *}$ & $.256^{* *}$ & -.009 & 1 \\
\hline $\mathrm{N}$ & \multicolumn{7}{c}{2819} \\
\hline
\end{tabular}

Note: **.and *. Significant at the $1 \%$ and $5 \%$ levels, respectively (bilateral).

Analysis of the relationship between the structure of executive compensation, the choice of accounting policies and corporate value: After the correlation test, carrying on the regression analysis focuses on the established model. The following table 3 shows the summary of models 1,2 , 3 and4.

Table 3: Model Regression Results

\begin{tabular}{llllc}
\hline Target & Model 1 & Model 2 & Model 3 & Model 4 \\
\cline { 2 - 5 } Cons & Coefficient & Coefficient & Coefficient & Coefficient \\
\cline { 2 - 5 } FAR & $10.259^{* *}$ & $1.666^{* *}$ & $9.926^{* *}$ & $10.067^{* *}$ \\
ESS & & & $0.127^{* *}$ & $0.115^{* *}$ \\
\hline
\end{tabular}




\begin{tabular}{llllc}
\hline SIZE & $-0.389^{* *}$ & $-0.059^{* *}$ & $-0.373^{* *}$ & $-0.382^{* *}$ \\
PROFIT & 6.842 & 3.315 & 6.301 & 6.460 \\
PRP & $-0.001^{* *}$ & 9.339 & $-0.001^{* *}$ & $-0.001^{* *}$ \\
$\mathrm{IND}_{1-11}$ & Controlled & Controlled & Controlled & Controlled \\
YEAR $_{1-4}$ & Controlled & Controlled & Controlled & Controlled \\
Adjustment of R & 0.375 & 0.065 & 0.367 & 0.377 \\
F- Value & $89.87^{* *}$ & $11.291 * *$ & $87.113^{* *}$ & $86.131^{* *}$ \\
\hline Note: **.and *. Significant at the $1 \%$ and 5\% levels, respectively (bilateral).
\end{tabular}

\section{Conclusions and limitations}

Via empirical research, hypothesis 1,2 and 3 are all passing the regression analysis. It is proved that Companies with strong stimulation of shares have large proportion of equity compensation in executives' salaries structure and they are likely to categories the financial assets into short-term trading financial assets. Meanwhile, the value will be affected by the incentive under the managerial decisions changing into the same way, which is inclined to be trading financial enterprises, and the value will turn up into the higher current one. From the model 4 , due to the significantly correlation level under $1 \%$ as well as the coefficient of the value impact is 0.115 . Both of these mean that the intermediary effect is obvious while the executives structure is also correlation under $1 \%$ level, representing the part of the intermediary effect, whose ratio is $0.077 * 0.115 / 0.373=2.37 \%$, and the model 4 is validated. The incentive of stock as salaries may have effect on making decisions of managers resulting in achieving the company's value and improvement eventually. In sum, the influence of corporation's value from the executives' compensation structure is partly reached by the choosing accounting policy.

The intermediary function of choosing accounting policy is validated in the paper. However, the improvement of the value of corporations is affected by multiple facets, and many targets are limited in the profit statement, which will cause the partly existence of the intermediary effect of the accounting policy and relatively small impact.

\section{Acknowledgments}

The author is very grateful to the anonymous reviewers for their constructive comments and suggestions that have led to an improved version of this paper. The work was supported in part by the Fundamental Research Fund for the Central University of China (No.2012B13814).

\section{References}

[1]Watts, R. and J. Zitmnennan, Positive Accounting Theory [M]. Prentice Hall.1986.

[2]Abdel-khalik.A.R. The Effect of LIFO-Switching and Firm Ownership on Executives'

Pay[J].Journal of Accounting Research.1985.

[3]Healy P. The Impact of Bonus Schemes on the Selection of Accounting Principles[J].Journal of Accounting and Economics, 1985.

[4]Beatty.A.and Weber.J. The Effects of Debt Contracting[J].The Accounting Review.2003.

[5]M.C.Jensen,W.H.Meckling. Theory of the Firm: Managerial Behavior, Agency Costs and Ownership Structure[J].Journal of Financial Economics,1976.

[6]Stulz, René. Managerial control of voting rights: Financial policies and the market for corporate control[J].Journal of Financial Economics 1988.

[7]Zhang Junrui, Zhao Jinwen, Zhang Jian. Analysis of senior management incentive and listed Corporation operating performance relationship empirical. [J].Accounting Research.2003.

[8]Wang Kun. The listed Corporation accounting policy choices and the value of the company.[J]. Communication of Finance and Accounting.2011. 
[9]Ye Jianfang, Zhou Lan, Li Danmeng, Guo Lin. The management motivation, the choice of accounting policies and accounting earnings management [J].Accounting Research.2009.

[10]Zhang Li. $\mathrm{T}$ The choice of accounting policies and corporate earnings management classification of financial assets. Master. Southwestern University of Finance and Economics.2010.

[11]He Hui. Between the classification of financial assets and executive compensation between [J]. Accounting Monthly.2011.

[12]Mehran Hamid, Executive compensation structure, ownership, and firm performance[J], Journal of Financial Economies, 1995(38),p163-184 